\title{
Affective Limitations in Second Language Acquisition by Spanish Adult Learners in Vocational Training Programs
}

Limitaciones afectivas en la adquisición de una segunda lengua en aprendices españoles adultos en programas de entrenamiento vocacional

Limitações afetivas na aquisição de uma segunda língua em aprendizes espanhóis adultos em programas de treinamento vocacional

Sergio BeRnal Castañeda

University of Seville, Sevilla, España Orcid: http://orcid.org/0000-0003-498I-8906

Received: 2017-06-01

Accepted by peers: $2017-06-22$
Send to for peer review: 2017-07-20

Approved: 2017-07-21

To reference this article in APA style / Para citar este artículo en APA / Para citar este artigo Bernal Castañeda, S. (2017). Affective limitations in second language acquisition by spanish adult learners in vocational training programs. Latin American Journal of Content and Language Integrated Learning, 10(1), 133-160. doi:10.5294/laclil.2017.10.1.6 
ABSTRACT. This article aims to show and explain the growing motivational, personal or affective difficulties that unemployed adult learners are currently facing in the English subject when they decide to retake their education in age-diverse Vocational Training Programs in the Spanish educational system. The results presented in this article are based on a multiple case qualitative study research directed in two different areas. The participants were vocational training teachers who participated in a semi-structured interview. They confirmed the increasing level of frustration and dropout rate that Spanish adult students are experiencing in the L2 subject of these programs, mostly due to their oral and comprehension skills. The results of this article show the numerous obstacles of adaptation to the L2 contents and methodologies that adult learners face; generally because they are surrounded by adolescent or younger classmates who have more experience in the foreign language and a wider linguistic knowledge. It is further explained how this age heterogeneity in the English classroom leads to difficulties in the linguistic acquisition, lack of adaptation to current L2 teaching methodologies and lack of inclusion in the rest of the group, due to motivational limitations derived from fear of ridicule, self-imposed affective barriers and anxiety in the English classroom.

Keywords: Adult teaching; English teaching; motivation; new teaching methodologies; age diversity.

RESUMEN. El presente artículo da cuenta de las crecientes dificultades del orden motivacional, personal o afectivo que enfrentan los aprendices desempleados de inglés cuando deciden retomar su educación en los Programas de Entrenamiento Vocacional para diversas edades en el sistema educativo de España. Los resultados que aquí se presentan están basados en un estudio de caso cualitativo múltiple desarrollado en dos áreas diferentes. Los participantes fueron profesores del área vocacional, quienes tomaron parte en una entrevista semiestructurada. Ellos confirmaron el creciente nivel de frustración y deserción que los estudiantes españoles adultos experimentan en el aprendizaje de una segunda lengua en estos programas, esto debido en gran medida a sus habilidades orales y de comprensión. Los resultados de este estudio muestran los numerosos inconvenientes de adaptación que esta población de adultos experimenta con relación a los contenidos y a la metodología de aprendizaje de la segunda lengua; generalmente estos aprendices están rodeados por adolescentes y aprendices jóvenes, quienes poseen más experiencia con la lengua extranjera y un conocimiento lingüístico más amplio. Se explica más adelante cómo esta heterogeneidad en el salón de clase conlleva dificultades para la adquisición de la lengua, la falta de adaptación a las metodologías de enseñanza actuales y la falta de inclusión con respecto al resto del grupo, debido a limitaciones motivacionales derivadas del miedo al ridículo, a las barreras afectivas autoimpuestas y a los niveles de ansiedad en el aula de clase de inglés.

Palabras clave: educación para adultos; enseñanza del inglés; motivación; nuevas metodologías de enseñanza; diversidad en edades.

RESUMO. O presente artigo apresenta as crescentes dificuldades de ordem motivacional, pessoal ou afetiva que enfrentam os aprendizes de inglês desempregados quando decidem retomar sua educação nos Programas de Treinamento Vocacional para diversas idades no sistema educativo da Espanha. Os resultados que aqui se apresentam estão baseados num estudo de caso qualitativo múltiplo desenvolvido em duas áreas diferentes. Os participantes foram professores da área vocacional que participaram de uma entrevista semiestruturada. Eles confirmaram o crescente nível de frustração e deserção que os estudantes espanhóis adultos experimentam na aprendizagem de uma segunda língua nesses programas, isso devido, em grande medida, a suas habilidades orais e de compreensão. Os resultados deste estudo mostram os numerosos inconvenientes de adaptação que essa população de adultos experimenta com relação aos conteúdos e à metodologia de aprendizagem da segunda língua; geralmente esses aprendizes estão rodeados por adolescentes e aprendizes jovens que possuem mais experiência com a língua estrangeira e um conhecimento linguístico mais amplo. Explica-se mais adiante como essa heterogeneidade na sala de aula implica dificuldades para a aquisição da língua, a falta de adaptação às metodologias de ensino atuais e a falta de inclusão com relação ao restante do grupo, devido a limitações motivacionais derivadas do medo do ridículo, às barreiras afetivas autoimpostas e aos níveis de ansiedade na sala de aula de inglês.

Palavras-chave: diversidade em idades; educação para adultos; ensino de inglês; motivação; novas metodologias de ensino. 


\section{Introduction}

In recent years, the Spanish society has witnessed a social and economic crisis that has affected its population in numerous ways. Budgetary cuts in education are not without controversy as they risk the quality education, with students as the main victims of this situation. At this juncture, special attention to economic, social and ideological problems has been paid; however, we tend to marginalize a segment of society that, overwhelmed by the current job insecurity and unemployment are forced to leave the professional field and retake their education after they have been out of the system for many years, even decades (European Commission, 2015). This research will focus on English teaching for adults, an educational practice that until recent years was virtually unexplored and that lately has experienced an increasing popularity in Spain.

The economic crisis marks an emergent educational reality in Spain. Vocational training teachers have recently observed an increasing registration rate of students over forty years of age who return to school after years of professional experience. Generally, these students are unemployed professionals who find themselves competing against younger and highly educated candidates for a job position. Thus, they are forced to continue their education in order to improve their academic experience or obtain compulsory certificates and professional diplomas, as also stated in Egetenmeyer (2010), Schmidt-Hertha, Krasovec \& Formosa (20I4) and Halttunen, Koivisto \& Billet (20I4).

Due to certain recent educational changes seen in our National Educational Agreement (Spanish LOE), all Intermediate and Advanced Vocational Training Programs now last two thousand hours and include English as a compulsory subject. All changes and developments done in Vocational Education and Training can be seen in the Organic Law 5/2006 on Vocational Education (Spanish LOE) and, most recently, in the Royal Decree 5/20I4 and the Government Education Order ECD/IO3O/20I4. In this new panorama, English teachers find mixed groups composed of adolescent and young students who have at least learned English as a second language ("L2" hereafter) in Primary and Secondary School (approximately 8-1o years) and adult students over 
forty or fifty years old who have never studied English before (until the 80's, French was the preferred foreign language in school plans in Spain), or lost contact with the language for a long period of time, showing a weak or fossilized knowledge of English.

Vocational training teachers have recently come to realize how this new panorama is making a radical change in post compulsory education, affecting both teachers and students. It is becoming more common to see adolescent students sharing books with classmates who are close to retirement. Diversity, which mostly refers to ethnicity, sociocultural aspects, and gender must now highlight age as a part of its definition.

\section{Theoretical background}

Adult learners generally show concrete, fixed and definite characteristics that tell them apart from their younger counterparts. The theory of adult teaching or lifelong learning focuses on heterogeneous students with different needs and objectives, so the teaching process must be adapted to this plurality (Castañeda, 20I6; Knowles et al. 200I; Käpplinger \& Robak, 20I4; Lou, 2017 and Ramos, Anton, Casaponsa \& Duabeitia, 20I7). According to Knowles (200I), adult students generally present concrete and fixed objectives, willing to learn voluntarily and showing a great cognitive matureness that is enriched by the professional experience acquired until the point of their comeback to education.

The assumption that adult students cannot respond to certain learning strategies in the same positive way as younger students do is defended by various authors such as Knowles et al. (200I), Käpplinger and Robak (20I4) and most recently Hwang, Hsu, Lai and Hsueh (20I7). In the context of a rapid changing technological and globalized world, adult students are starting to retake their education with the intention of acquiring new knowledge, abilities, competences, interests and values that can help them prepare to the current events and continue to achieve fixed objectives. Firstly, they are autonomous students who do not fully depend on the teacher to continue learning on their own. They also seem to be active and responsible, committed to fulfilling 
objectives and own benefits, showing motivation to achieve them. Additionally, these students are usually subjective and with a strong, individual identity, therefore their participation in class is a very rich empirical source difficult to find in other age groups. Adult students are learners who have already experienced a maturational process that facilitates the learning process and it is the teachers' duty to support and continue to help increase this attitude (Egentenmeyer \& Nuissl, 20Io; English \& Mayo, 2012 and Kirkwood, 2012).

Theoretically, the new educational reality seen in Vocational Training Programs regarding age diversity should convey a drastic change in study planning and curricula, adapting to all students' needs and modifying teaching methodologies if necessary (Boshier, 2006; English \& Mayo, 2012; Foley, 2004; Kirkwood, 2012 and Leberman \& MacDonald, 2008).Teachers must therefore instruct in an individualized way, adjusting to the particular needs of the students and trying to soften the added limitations that diverse age groups cause, especially in the English classroom.

In that concerning adult L2 learning, we observe a double barrier that hinders the teaching and learning process; on the one hand, the neurological limitations of human beings that limit foreign language acquisition due to an older age; on the other hand, the affective variables such as the feelings of fear, hesitation, lack of motivation and confidence, low self-esteem and language anxiety that the majority of adult students face in the English subject (Domyei, Csizer \& Nemeth, 2006; Dornyei \& Ushioda, 2009; Hall \& Goetz, 2013 and Lasagabaster, 20I4). This contrasts with the greater linguistic ability and skill shown by younger students who have been educated in a system in which the importance of acquiring an L2 has become a priority.

A great amount of research has been done in order to study the neurological limitations that slow down or hinder foreign language acquisition in adults. As traditionally proven by Penfield (1969) and popularized by Lenneberg (1967) in Biological Foundations of Language, there is a time period or "window" during puberty and adolescence after which the ideal, native foreign language acquisition is biologically impossible. According to this hypothesis, there is a critical period that does not allow the complete mastery of a foreign language if L2 learning and first exposure begin after puberty. If these studies are extrapolated to the 
current age heterogeneity in the English classroom, we can observe that both students and teachers face an educational barrier difficult to overcome.

Additionally, it is increasingly frequent to find adult students who had a previous basic or medium level of English and throughout the years forgot it due to inactivity and lack of practice, forcing them to make a great effort now in order to remember what they had previously learned. This first barrier in L2 acquisition could be defined with the hypothesis "younger = better" developed by Lenneberg (I967). However, this perspective seems to be rather alarmist and supports the neurological superiority of younger students when learning foreign languages, an assumption that can be very well refuted if the adult student's attitude, motivation, and predisposition towards achieving the L2 are adequate (Krashen, 2009; Park \& Reuter-Lorenz, 2009, Reuter-Lorenz \& Cappell, 2008 and Vanhove, 2013).

Numerous traditional studies have been carried out to deny the prevalence of age-derived neurological factors that even reject the existence of such Critical Period Hypothesis, defending the possibility of native acquisition in adult age. In recent researches, as seen in Park \& Reuter-Lorenz (2009) and Reuter-Lorenz \& Cappell (2008), functional imaging studies have demonstrated reliable increases in prefrontal activation in adult students as a way for the brain to compensate the decrease in neuroplasticity and hence the ability to learn a second language at a native level. They propose the scaffolding theory of aging and cognition (STAC), which is a process present across the lifespan that involves use and development of complementary, alternative neural circuits to achieve a particular cognitive goal. However, this process greatly depends on the learner motivation and predisposition to learning, and it can be easily hindered if the adult student's affective filter is blocked.

According to prior research, and based on the results analysed throughout this work it seems logical to accept the influence of neurological factors; however, affective agents are more significant if we analyze the obstacles that adult students face when returning to school, as suggested by the participants of this research. In this sense, the anxiety experienced in the L2 classroom due to the lack of motivation and low self-esteem widely overcome any kind of "biological 
foundation of language" when analyzing the reasons of the general failure rate among adult students who try to learn foreign languages (Chiswick \& Miller, 2008; Du, 2010; Hakuta \& Long, 2005; Schouten, 2009; Scott, Zhang, Wang, Vadlamudi \& Brann, 20I2, Singleton, 2005 and Vanhove, 2013). On the other side of the spectrum, not only adult students are deeply affected by age-diverse groups in L2 learning. In this sense, we must not forget that younger students who have more English knowledge might also become demotivated in English class because of the slowed down pace of the lessons, mostly because adult students usually need a more repetitive and slower learning.

One additional feature that may prevent adult students from acquiring L2 knowledge properly is the old habit in outdated methodologies and ways of study, as stated in Lee and VanPatten (2003). Traditionally, in the Spanish education system, lesson plans and curricula in schools and colleges has usually relied more on grammar and memorizing lists of vocabulary and $\mathrm{A} \rightarrow \mathrm{B}$ translation, with no attention to the communicative approach or the L2 oral skills. As Castañeda (2016) and Méndez García (20I0) have stated, due to this excessive attention to more theoretical and receptive skills, adult students were never sufficiently exposed to foreign languages and have not enjoyed the opportunity of getting involved in L2 from earlier stages of life, which is the ideal period to begin acquiring foreign languages. Most importantly, the later learners start receiving input in L2, the harder it becomes for them to acquire an advanced or expert level, especially in the most "fragile" aspects of foreign language, such as morphology and morphosyntax or phonology and pronunciation (Goldenberg, 2008; Hayes, 2009; LoMonico, 2014 and Kurt, 2015).

Currently, these students come from an obsolete and non-practical system and today they are together in classroom with a new generation of L2 younger students who have completed their studies in a more communicative way, many of them having been educated at bilingual schools. Adult students are trying to cope with new L2 learning methodologies that usually keep them away from their "comfort zone", which is grammar, vocabulary and the security of a textbook. As soon as teachers aim to implement new learning strategies, language anxiety increases among adult students. New communicative and dynamic L2 learning strategies such as Content Language 
Integrated Learning (CLIL) (Lorenzo, Trujillo, \& Vez, 20II and Lasagabaster, 20I4), the Action-Oriented Approach (Piccardo, 20I0) or the newest L2 learning strategies based on new technologies and social networks are usually rejected by these students. Teachers should try to implement them progressively and in an ecliptic way, trying to use them alternatively and combined with traditional ones, so that adult students can adapt and avoid frustration.

One of the main limitations of adults attempting to work with new methodologies is related to fossilization in morphosyntax and pronunciation, as stated in Singleton (200I), Birdsong (2006) and Krashen (2009) because adult learners tend to systematize errors and repeat them. This limitation leads to fear of ridicule when speaking in public and a sharp decrease in confidence and self-esteem, which affects the possible satisfactory outcome of any communicative learning strategy. These elements play a negative role in L2 learning, together with the decrease in memory, attention skills and information processing speed that adult students experience at an older age -which clearly contrasts with the apparent ease to learn foreign languages by their younger counterparts-. All these disadvantages certainly do not help adults to learn English and they frequently end up frustrated and demotivated in a situation that might lead to academic dropout.

With the goal of raising students' motivation, teachers will have to select and work with those teaching methodologies that fit their learners' needs better, regardless of their age or any other heterogeneity aspect and always trying to work with individualized teaching methods to avoid demotivation in the group, as seen in Boshier, (2006); Egentenmeyer \& Nuissl, (2010); English \& Mayo, (2012); Foley, (2004); Leberman, MacDonald \& Doyle, (2008); Lee \& VanPatten, (2003) and Kirkwood, (2012). One of the most practical and useful teaching proposals are the ones closely related to collaborate or peer work methodologies based on their branch specificity, as well as the use of tasks or activities focused on real practice that could offer them experience for their future line of work. These proposals are the most used options by teachers as a means to keep motivation in both young and adult students (Barkley, Major \& Cross, 2005; Brockett \& Hiemstra, 2007; Connolly, 2008 and Merriam \& Bierema, 20I4). 
In order to delve into the realm of motivation towards foreign language learning by adults in a more profound way, it is important to highlight the existence of distinct variables that entail limitations for adults when acquiring the L2: language anxiety in the English classroom, adult students' self-concept, sense of L2 learning success and L2 enjoyment:

" Language anxiety: Anxiety has become one of the most important variables in adult L2 learning, with students facing an elevated pressure to acquiring a second language at the same pace or rhythm as their younger counterparts. Very frequently the outcome is not as positive as adults would expect, which leads to stress and a very high pressure in class. In recent studies, Gkonou, Daubney \& Dewaele (2017) argue that language anxiety is a complex and dynamic construct and that it is linked to other psychological variables, such as the self and personality.

» Self - concept: Adult students' self-concept is also crucial and it clearly and directly affects motivation in L2 class (Mercer, 20II). Adult students retake their studies completely demotivated and their self-confidence levels are a barrier to language acquisition. They tend not to value themselves and believe they cannot succeed in L2 learning, a fact that is also influenced by constant comparisons with their younger counterparts. Adult students usually present a distorted self- concept or image due to lack of confidence in themselves and insecurities towards L2 learning and new methodologies. Occasionally, the lack of self-esteem among these students aggravates learning inability because they usually feel inferior and less capable than the rest of their younger counterparts. This fact causes an increase in the frustration rate among adults and a long-term rejection to foreign languages. They tend to believe that L2 learning at an advanced age cannot be successful, which is precisely another barrier to acquisition, the concept of success or attribution theory.

» Learning success: According to the attribution theory, each adult student attempting L2 learning has a distinct and unique way to approach the concept of success in learning (Gobel \& Mori, 2007 and Gobel, Thespiri, \& Pojanapunya, 2010). In the education context of Vocational Training Programs, what adult students need to realize is that success in L2 learning does not derive from a great 
knowledge of every grammatical rule or an extended and varied lexicon, but rather from the ability to communicate and transmit information, regardless of the linguistic performance exclusively.

» L2 enjoyment: Teachers are constantly seeking an increase in students' motivation. Interest and enjoyment towards learning a foreign language are the key points of success in linguistic education. When teaching a second language subject in age heterogeneous contexts, a sense of enjoyment must be found. Teachers should find a way to get to their students through new insights and strategies that contemplate age diversity and help reduce language anxiety (Dewaele \& MacIntyre, 20I4).

As also defended by Krashen (2009), adult students usually tend to create a self-imposed affective barrier that prevents them from opening themselves to L2 learning and this barrier will not be opened as long as their attitude towards L2 learning does not change. Consequently, keeping a high level of motivation among adult students becomes one of the main factors that assures a successful L2 acquisition, thus avoiding school dropouts, a burden that specifically affects adult learners who return to school after a long hiatus (European Commission, 2015). In this sense, motivational aspects seem to gain significance over any neurological limitations that adult learners may present. A high level of motivation and positive attitude towards L2 learning is an essential aspect that can even overcome any biological impediment coming from an older age.

The importance of motivation in the L2 classroom is also ratified by the theory of the affective filter, one of the prime works by Stephen D. Krashen (2009). Through this theory, he explains that the foreign language acquisition process is directly related to emotions, attitude, feelings and the mood of the learner. Unfortunately, this emotional state is currently unstable in Vocational Training L2 classrooms because there are various factors that increase frustration among students: rivalry or comparisons between young and adult learners, impatience towards L2 teaching process, indifference towards contents, weak teacher-student relationship, obstinacy, low self-esteem, anxiety, excessive shyness of speaking in public, etc. Additionally, teachers must convince adult students about the possibility of fully 
learning a foreign language without achieving a native pronunciation. As also stated by Meisel (20II), Singleton (200I) or Trofimovich (20I I), the absence of a perfect accent will not prevent adults from getting a proper communicative competence and neither will it hinder the real use of the L2 in its social or professional spheres. It is necessary to make them understand that learning a foreign language implies acquiring certain skills that allow them to manage themselves with the L2 language and culture in real life, being a native or expert knowledge not indispensable to succeed in the L2 context, as supported by English \& Mayo, (20I2), Kirkwood, (20I2) and Castañeda (20I6). As Oxford (2003) stated, a good language learner is not determined by his age, but his ability to control his emotions and attitude towards learning.

\section{Methodological design}

The main idea of this research is to make visible and recognize a new academic reality that has been practically ignored in educational studies: that is, the existence of age-diverse groups in Vocational Programs with adult learners who face affective limitations that hinder their language acquisition and make them struggle with frustration and the constant desire of dropping out. The attention given to this topic has been scarce, though. Nationwide, there are no clear references to adult students in national decrees or study plans. In reference to Attention to Diversity or Special Needs, no special attention is paid to Andragogy or permanent students as a matter that needs help. In this sense, this project arises from the need to show this new educational situation and bring to light all the limitations and obstacles that Spanish adult students are facing in the English classroom, so that the educational community can become aware of this problem and make the necessary amendments and methodological improvements to support this new type of students.

The results presented in this article are based on a multiple case qualitative study research directed in two different areas, following the work of Robert E. Stake (2006) on multiple case analysis. The information obtained through this research shows teachers' and students' 
experiences in Intermediate and Advanced Vocational Training Programs in public and private teaching centers in Spain, where the L2 learning has recently become compulsory.

\section{Participants}

Twenty teachers from Vocational Training Programs volunteered to participate in a semi structured interview. The participants selected work with age-diverse groups where adult students find serious limitations in the acquisition of the foreign language. From their teachers testimony and point of view, we will discern and analyze the learning difficulties that adults are suffering in the Spanish educational system when retaking education after a long hiatus or prolonged discontinuity.

All the participants (i3 female, 7 male) come from student centers in the Seville Aljarafe rural area and western Costa del Sol in Malaga (south of Spain). All teachers are in charge of diverse groups composed of different age and sociocultural backgrounds.

The teachers who have participated in the research study belong to the Intermediate Professional Training Programs of Management and Administration, Pharmacy and Health-care, Secretarial Studies and Trade and Marketing and the Advanced Professional Training Programs of Administration and Finances, Dietetics and Nutrition, PreSchool Education and Travel Agency and Events Organization.

\section{Instruments of data collection}

A semi structured interview was done to every participant, each one composed of forty-five open ended questions that aimed to collect information related to the seven categories in which this research was divided, namely: description of teaching centers, new trends in lifelong learning, age-related diversity, affective aspects of adult L2 learning, neurological aspects of adult L2 learning, L2 learning skills and teaching methodological strategies. The research period lasted approximately four months, from February to May 2015. 
The questions selected for this structured interview are divided into different categories for their analysis, corresponding to the notions of "previous experience with age-diverse groups", "group characteristics", "affective aspects", "neurological aspects", "teaching strategies" and "language skills" as a means to obtain a holistic approach of the different components concerning adult learning in the L2 classroom. In the results of this research, we will focus more in depth in the category of "affective aspects", "neurological aspects" and "teaching strategies", as they turned out to be more suitable for the motivational focus of our study.

\section{Data analysis}

After the data collection, the transcription and analysis of the information was performed through the qualitative analysis data program Atlas.ti. After an arduous codification and categorization process of the information collected (implementation of a system of codes and categories, analysis of topic transversality, selection and dismissal of transcendental and redundant information respectively, elaboration of diagrams of categorization and triangulation) the results were interpreted and the conclusions were drawn.

\section{Ethics}

The participants' personal information has remained anonymous at all times and there is no piece of information that can identify them. In order to ensure such privacy, they were given an informed consent in which they authorized the interviewer, and therefore the University of Seville, to use the data provided for the investigation. In the same way, the interviewee was informed about the purposes of the interview and the purposes to be achieved, namely: publication, use of their contributions in congresses, conferences, etc. 


\section{Results}

The current period of transition in Spanish education arises one important issue regarding adult students and the possibility of inclusion and adaptation in the L2 classroom. This generation has been educated in a time when foreign languages were not as eminent as they are in current society and therefore they might not be fully conscious about the importance of acquiring second languages in order to return to the professional field.

In the course of this research we found out that adult students go back to school showing a different level of motivation from that of their younger counterparts. Adult dedication towards learning is far from the much more relaxed and indifferent attitude that teenagers and younger students generally have. However, even though adults show more responsibility and commitment to the studies, it is necessary to bear in mind that they come from a work force that has turned them down, leaving them unemployed and submitted to external pressures that are not easy to overcome. In this context, adults decide to return to the academic world as a desperate attempt to take advantage of their increased free time, seeking to further their education and skills rather than being completely inactive. As a result, and regardless of their stronger dedication and willingness to study, they generally show an initial low self-esteem, risking frustration and eventual dropout.

INT 2: "The most important thing when dealing with adult students is to always bear in mind that new students come completely demotivated and with a broken self-esteem due to the economic and social problems that our country has recently had. Adults return to school because their working fields have neglected them and they usually feel useless, pariahs of the society and teachers must not ignore this initial situation of low self-esteem."

This teacher talks about social outcasts and pariahs to explain the sensation adult students feel when they become unemployed and left out of their professional field. At this point, returning to school turns out to be complicated both for students and teachers because attitude towards learning is fully in line with learning successfully. 
As a general rule, the participants in this research agree on the fact that adult students show less motivation in the first term of studies, after which there is usually a decisive turning point. On the one hand, adult students could end up adjusting to the new dynamics and methodologies in the classroom, supported by teachers and classmates and eventually achieving successful learning. On the other hand, they could very well end up losing more motivation and dropping out when realizing how complicated it can be for them and eventually getting frustrated towards those academic barriers that seem unsurmountable. This second option is the one that our educational community must avoid at all costs. As the participant below explains, teachers must assure students that those academic barriers are not as hard to overcome as they conceive, trying to make them focus on the opportunities that L2 learning will bring them instead of the limitations they may encounter.

INT 5: "I think the main problem is that adults who return to school feel more detached from the rest of the group than they really are. Evidently, what they can never lose is motivation. I do understand it is easy to get lost when learning a language, especially at this age when L2 knowledge is not enough, but the real problem comes when they think that this whole situation is bigger than it really is. They come to class totally overwhelmed and we as teachers must explain to them that English is going to be useful and good for their professional future, to calm them down".

Furthermore, it seems interesting to contrast the initial motivation of both younger and adult students. With respects to the opinion of most of the teachers interviewed in this research, older learners shows a lower self-esteem due to past difficult experiences related to work and society while teenagers and younger students are not fully aware of the professional obstacles that can be currently found in Spain. However, their teachers also point out that adult students have a clearer idea of what they want to accomplish by returning to the Vocational Training Programs, their future aspirations and their decision to learn and get a proper training. In this context, younger students still feel quite lost and their long-term motivation is blurred. 


\section{L2 Motivation among adult students}

As analyzed through the different teachers' opinions and perspectives, Spanish adult students usually do not show a special interest in acquiring second languages. There is no real motivation to learn them because this generation was raised and educated in a close minded society that was not traditionally inclined to internationalization or cultural openness. Nowadays, it is true that adults are becoming aware of its importance when trying to apply for job positions. However, they are not naturally fond of L2 learning because they usually feel uncomfortable towards subjects in which memorization or study time are not enough to achieve successful learning.

INT I7: "In the first sessions of English, teachers are not going to be able to convince adults of the practical use and importance of a foreign language and motivate them right away. Adults already need to know that they will be part of a working field and a new society where international relationships and L2 knowledge is basic. I think they are motivated, but the problem is that the majority of them are scared of the difficulty it entails. Learning a foreign language is just terrifying to them".

Apart from the generalized concern towards L2 learning among adult students, fear of ridicule and lack of oral practice are some of the reasons that affect self-esteem and motivation in English class. The participants of this project express how difficult it is to raise such motivational level:

INT I6: "I really do not know how to keep my adult students motivated anymore. It is really difficult. Children can be motivated with anything, but adults are a whole different thing. I do not know, maybe I make mistakes as a teacher, but the fact is that we have had many adult students who have done internships in real companies at the end of the program and they would be sent back because their level of English was just not enough".

From the results of this research, it is evident that the lack of motivation among adult students is not necessarily the teachers' fault, but they must certainly be responsible for keeping all students interested in the subject, so certain methodological adaptations must be implemented in order to keep both younger and older learners 
motivated. However, it is noticeable how this intermediate position is really challenging for teachers. One of the most common options is to approach the subject with transversality, teaching it in relation to the rest of the subjects in the program using a specialized terminology from the particular field. Furthermore, following real tasks and situations applied to working practice seem to keep both younger and

older students motivated. New methodologies that aim to get away from traditional dynamics such as translation and grammar can be complicated to understand for adult students due to their lack of habit in these learning strategies but at the same time it can also raise their interest and motivation in the L2:

INT I4: "I think I have managed to engage all my students in English class precisely because of the practical scope I have used in the subject. They are studying something they like and know, so for the same reason they can also like English. I came to the classroom for the first time and said: 'Don't you think we're doing grammar here. It's not necessary for you to know what the Present Simple tense is."

\section{Language anxiety, self-concept and language success}

Language anxiety among adult students is one of the direct consequences derived from the use of new L2 communicative methodologies in age-diverse contexts. Students are not used to communicative strategies when learning foreign languages and adaptation is an arduous process. The participants explained how older students felt uncomfortable with new learning strategies when they had to participate actively in public, due to their supposedly inferior linguistic level. Anxiety frequently leads to lack of confidence in the classroom and adults' self-concept seems distorted:

INT 7: "They were nervous; you could tell they were really stressed all the time, struggling to understand and to achieve the levels of their younger mates, which was discouraging since they just couldn't get there. They had this misconception of what learning English should be."

The participant 7 analyzes the idea of "misconception" that adult students present towards learning a second language. They believe the final goal and most important achievement is to acquire native 
levels and grammar perfection. On the contrary, teachers repeatedly emphasize the real reason of learning a language, that is, communicative performance and the ability to manage themselves in foreign language situations. If adult students understand this concept, language anxiety levels in English class considerably diminish. Students must clearly understand why studying a second language is beneficial and what exactly language success means.

\section{Fear of ridicule and lack of confidence}

Another relevant finding in this research is the adults' tendency to feel fear of ridicule when participating in English class and the sensation of shame and lack of confidence they experience when utilizing foreign languages orally. As supported by all teachers interviewed, adult students born and raised in Spain have not usually been in direct contact with foreign elements due to the historically poor tendency of externalization in this country.

Nowadays the country is opening up to new frontiers and the conscience about the importance of L2 learning is raising. However, this growing conscience is not paralleled to a personal motivation that would encourage adults use the L2 without objection. According to their teachers, adults usually feel ashamed of their pronunciation or diction, so speaking in public turns out to be a greater problem for Spanish adults than it is for learners from other countries.

INT 4: "Adults have way more fear to social ridicule when they speak in English. However, younger students are more used to that, they chat with friends from other countries, they listen to music in English, they watch TV-series...so everything is more familiar to them, and it is like a second language. But for adults is like starting from zero at age forty, finding themselves thinking: 'Now I get to talk and these children will laugh at me!'."

This quote clearly shows the generational difference between adolescent and adult learners. The first has always been exposed to a more globalized society that has helped them open their horizons and find more L2 exposure, so learning will be more intense and they will make better use of new language methodologies. It is necessary to 
raise conscience for adults to open their minds to new language learning tools and create a habit to accept and learn from different cultural elements and languages with the objective of improving motivation.

The metaphor of the sponge has been widely used by teachers to explain that if foreign languages are learned from earlier stages of life within a communicative approach, the ability to retain oral structures and L2 general level will be more elevated in the future rather than beginning or returning to these studies at an adult age. However, some adult students have taken this metaphor too seriously and it has become the perfect excuse to hide their insecurities and limitations and self-impose psychological barriers that really do not exist and only disturb the L2 learning process. Teachers agree that adult students show more difficulties and must make a double effort to reach younger students' levels. However, they also defend that it is not convenient for adults to use this disadvantage to justify their limitations and keep a negative attitude. Adults need a motivational push and it is the teachers' obligation to pave the path for it.

INT I I: "I really do not think adults are less capable, but they create inexistent barriers. They just think it is going to be harder for them being older than the others and it is just not like that. It is not impossible, the only thing is that at this age they are already used to talk and express themselves in a particular way and they always tend to translate from Spanish to English. And that is precisely the mistake: direct translation. They need to accept the fact that one expression has an equivalent in English, not a direct, literal translation. It is harder for them due to a series of motivational, internal, psychological aspects, rather than ability."

Ultimately, it is important to take teachers opinion into account when they point out that even though psycholinguistic barriers are important in L2 acquisition, affective factors turn out to be the most significant aspect. It is precisely the effort and disposition to L2 learning that can have a positive effect and save adult students from the frustration that comes from their minor biological predisposition to foreign languages. Teachers strongly suggest that a bigger effort and higher interest in foreign languages make up for the less linguistic ability seen in older learners. 


\section{Frustration and dropouts}

One of the most relevant findings of this research shows that the loss of motivation in the L2 among adult students leads to negative consequences. This kind of students usually tends to make the best of their time in the classroom and knows what they want from their education. Therefore, as soon as they perceive they are not learning as they expected they would be, they will lose motivation and confidence in the class. This situation may lead to frustration and apathy towards English learning which can cause school dropouts, as can be seen in this quote:

INT 4: "There have been many dropout cases and academic frustration among adult students who did not get their certificate just because they failed English. And some of them had to look for some other programs and professional fields that did not require the L2. This has to be really demotivating for them; studying for two or three years and then leaving without a diploma."

Other teachers state that adult students create a self-imposed psychological barrier that prevents them from undertaking L2 learning from an optimist and positive point of view. From the very beginning, adults are overwhelmed and deny every possibility of improving under the belief that "they are simply bad at English and they will never be good at it". In this case, it is not in the teachers' hands to solve the situation, since it is the student the one who needs to open his/her mind towards new knowledge and training:

INT I2: "There are always cases of frustration. The best thing is to keep on encouraging them and make them abandon the feelings of inability to learn in the L2. When teachers decide to do a Listening in class, adult students immediately would say 'I can't do that, it's too difficult for me', that is only in their minds. I tell them that the problem is that they neither listen nor try; they only listen to the voice in their heads telling them that they are not good enough for it. You need to keep an eye on some students from the beginning so you do not lose them."

In these situations, teachers decide to transmit confidence and assurance to their students, telling them that improvement would eventually come in the process of L2 learning. It is necessary for students 
to focus on the process of learning itself rather than neglecting it from the beginning without even trying:

\section{Discussion}

This research shows a new educational reality observed in Intermediate and Advanced Professional Training Programs in Spain, specifically in the L2 classroom due to the recent massive income of adult students as a result of the country's economic crisis (European Commission, 20I5). As a consequence, we can witness the obstacles and limitations that both adult learners and teachers must overcome in order to facilitate the teaching and learning process in groups of age heterogeneity, grouped in a series of affective and neurological variables:

Among the affective variables, we observe a general tendency to fear of ridicule in L2 oral skills in adult learners. This factor, in addition to the lack of self-esteem and L2 insecurity causes frustration in the classroom (Krashen, 2009; Lasagabaster, 2014 and Mercer, 20II). The majority of the participants in this project, based on their longtime experience working as English teachers in Vocational Training Programs in the Spanish educational system, confirm that this fear can be generalized as characteristic of Spanish students because our country's L2 exposure has traditionally been more limited than in other EU countries.

We observe a distinctive way to approach the concept of success (attribution theory) in learning (Gobel \& Mori, 2007; Gobel, Thespiri, \& Pojanapunya, 20I0). In the education context of Vocational Training Programs, teachers are trying to make adult students realize that success in L2 learning does not derive from a great knowledge of every grammatical rule or an extended and varied lexicon, but rather from the ability to communicate and transmit information. Learning a foreign language should also be done in a way that students find a sense of enjoyment (Dewaele \& MacIntyre, 20I4, 20I4).

Teachers have also witnessed a great level of language anxiety among adult students who tend to constantly compare themselves to their younger counterparts. The pressure of leaning the L2 and use it 
orally with new communicative methodologies affects their self-esteem and it frequently leads to losing their confidence.

On a more psycholinguistic note, the decrease of the learners' L2 neurological ability is a major driving force of inequality in Professional Training Programs, as stated by Birdsong (2006). However, throughout this research, it has been analyzed that regardless of their psycholinguistic reasons, adult learners tend to create self-imposed affective barriers by which they believe their age is already a definite restraint to L2 learning, being this factor the vital reason of generational inequality in the English classroom (Krashen, 2009, Park \& Reuter-Lorenz (2009) and Reuter-Lorenz \& Cappell (2008).

According to the participants, frustration among adult students increases due to the academic shock they experience towards new L2 teaching methodologies. Due to age heterogeneity in the English classroom, both adult and younger students usually get frustrated and lose motivation in the process of L2 learning, which shows how significant affective factors are when acquiring a foreign language, as also seen in Boshier, (2006); Egentenmeyer \& Nuissl, (20I0); English \& Mayo, (20I2); Foley, (2004); Leberman, MacDonald \& Doyle, (2008); Lee \& VanPatten, (2003) and Kirkwood, (2012). In this study it has been stated that the dropout rate is dangerously elevated, frequently due to the lack of adaptation to the new academic frame after a long hiatus without attending school, and especially, because of the difficulty it entails to study a foreign language in an intermediate level at an advanced age.

The teachers participating in this research have also stated that the teaching methodological change and transition from translation and grammar techniques to real communicative approach has been fundamental to raise awareness about learning new foreign languages among students. Importance of the L2 subject has increased and lessons are performed in a more practical, realistic and dynamic way, as anticipated by Castañeda (20I6), García (20I0), Lorenzo, Trujillo, \& Vez (20I I), Lasagabaster (20I4) and Piccardo (20I0).

Another conclusion drawn in this research regards entrepreneurship and initiative as two crucial aspects when it comes to learning a foreign language. Obviously, the number of lessons offered in college is not enough to achieve a sufficient communicative level that allows students to manage themselves in real situations in the L2. For this reason, 
it seems necessary for them to show interest in learning and improving on their own. In this globalized era, it is easier to find exposure to the L2 through media, social networks, movies and television, books, etc. or even through exchanges and cultural programs with native speakers or abroad. However, teachers suggest that adult students only cling to school hours and completely refuse to practice outside the classroom, showing scarce motivation to foreign language exposure.

As observed throughout this research, the educational community deeply values the efforts that adult students are making to adapt to their new academic lives and teachers try to raise their hope and avoid their frustration. However, apart from the linguistic obstacles that adults are facing in the L2 classroom, teachers seriously wonder what happen to those students over fifty who return to school as the ultimate way to engage themselves in the professional field again, in a business world with excessive rivalry where highly prepared job-seeking youngsters are taking over.

We now witness how unemployed adult students not only face obstacles in the acquisition of new subjects like English, but they also feel emotionally and personally detached from a society that has turned its back to them, leaving them professionally and economically inactive. Far from giving up, adults who return to school remain hopeful that education and training will provide them with the necessary skills to take part in the work force again. In this case, teachers believe that, regardless of the drop-out risk and academic frustration, these students can strengthen their weakest points, always counting on the support of the educational community, on new real and practical methodologies that really motivate them and on a collaborative and cooperative learning environment that paves the way for inclusion in such diverse, heterogeneous field of studies.

After the analysis of the results in this project, an important question arises: "What is about to happen?" It is evident that the economic crisis in Spain is not some punctual problem that this country is experiencing, but a major difficult political, economic and social juncture that mostly affects unemployed adults over fifty. Some critics continue writing about a "lost generation", young highly prepared professionals who settle for a job for which they are overqualified. However, we 
must not forget about older professionals who became unemployed at a risky age and look for other means to move forward.

\section{Study limitations}

A major obstacle for this study has been the access to the participants. The different institutions that offer Professional Training Programs were easy to find through our regional teachers' center and various educational websites. However, contacting these institutions and their English teachers was the a true problematic process. The selection of teaching centers could not be done according to the real interest and circumstances, being dependent on the teachers' appointments and schedules. In addition, the majority of teaching centers were not interested in participating in any kind of research.

Apart from the lack of research solidarity, there are not many institutions that offer English in both Intermediate and Advanced Professional Training Programs, which significantly reduced the sample. Lastly, interviews were long and teachers sometimes could not dedicate as much time as the researchers wished they had.

Future investigations in this matter should focus on adults as main participants rather than teachers. The researchers in this study will continue to make efforts to provide a voice to this vulnerable group and try to understand their point of view, collecting firsthand information about their main obstacles with English teaching methodologies and the L2 skills where they find more limitations in the process of learning.

\section{References}

Barkley, E., \& Cross, K. (2005). Collaborative learning techniques: A handbook for college faculty. San Francisco, CA: Jossey-Bass.

Birdsong, D. (2006). Age and second language acquisition and processing: A selective overview. Language Learning, 56, 9-49.

Boshier, P. (2006). Perspectives of quality in adult learning. London: Continuum. 
Brockett, R., \& Hiemstra, R. (2007). Self-direction in adult learning: Perspectives on theory, research, and practice. London: Routledge.

Castañeda, S. B. (2016). Methodologies for Teaching English to Adult Students in Spanish Vocational Education Programs. Journal of Professional, Continuing and Online Education, 2(I).

Chiswick, B. R. \& Miller, P. W. (2008). Linguistic distance: A quantitative measure of the distance between English and other languages. Journal of Multilingual and Multicultural Development, 26(I), I-I I.

Connolly, B. (2008). Adult learning in groups. Maidenhead, England: Open University Press.

Deawele, J. M., MacIntyre, P. (2OI4). Enjoyment and anxiety in second language communication. Cape Breton University.

Dornyei, Z., Csizer, K. \& Nemeth, N. (2006). Motivation, language attitudes and globalisation: A Hungarian perspective. Clevedon [England]: Multilingual Matters.

Dornyei, Z. \& Ushioda, E. (2009). Motivation, language identity and the L2 self. Bristol, uk: Multilingual Matters.

$\mathrm{Du}, \mathrm{L}$. (2010). Assess the Critical Period Hypothesis in Second Language Acquisition. English Language Teaching, 3(2), 219-224.

Egetenmeyer, R. (2010). Teachers and trainers in adult and lifelong learning Asian and European perspectives. Franfurt am Main: Peter Lang.

English, L. \& Mayo, P. (2012). Adult education and the state: Gramsci, the historical materialist tradition and relevant others. European Journal for Research on the Education and Learning of Adults, 3(I), I I-27.

European Commission. (2015). Common European framework of reference for languages: Learning, teaching, assessment. Cambridge, U.K.: Press Syndicate of the University of Cambridge.

Foley, G. (2004). Dimensions of adult learning. Adult education and training in a global era. Open University Press.

Gkonou, C., Daubney, M. \& Dewaele, J. M. (2017). New Insights into Language Anxiety Theory, Research and Educational Implications. Multilingual Matters.

Gobel, P. \& Mori, S. (2007). Attribution and learning English as a foreign language. ELT Journal.

Gobel, P., Thepsiti, K., \& Pojanapunya, P. (20I0). Attributions for Performance: A Comparative Study of Japanese and Thai University Students. JALt Journal, 32(I), May, 5-28. 
Goldenberg, C. (2008). Teaching English Language Learners. American Educator, 78(4), IOIO-IO38.

Hakuta, K., Bialystok, E. \& Wiley, E. (2003). Critical Evidence: A Test of the Critical-Period Hypothesis for Second-language Acquisition. Psychological Science, I4(I), 3I-38.

Hall, N. \& Goetz (2013). Emotion, motivation, and self-regulation a handbook for teachers. Bingley, uk: Emerald.

Halttunen, T., Koivisto, M., Billett, S. (Eds.). (20I4). Promoting, assessing, recognizing and certifying life- long learning: International perspectives and practices. London, United Kingdom: Springer.

Hayes, D. (2009). Non-native English-speaking teachers, context and English language teaching. System, 37(I), I-I I.

Hwang, G. J., Hsu, T. C., Lai, C. L. \& Hsueh, C. J. (2017). Interaction of problem-based gaming and learning anxiety in language students' English listening performance and progressive behavioral patterns. Computers and Education, 106, 26-42.

Käpplinger, B., \& Robak, S. (20I4). Changing configurations in adult education in transitional times: International perspectives in different countries. Peter Lang.

Kirkwood, A. (20I2). ICT in higher education: Policy perspectives. In ICT Leadership in Higher Education. Conference held 24-26 February 2013, Hyderabad, India, (pp. 36-43).

Knowles, M. S., \& Knowles, M. S. (200I). Malcolm Knowles Theory of Andragogy. Elements, I-3.

Krashen, S. (2009). The monitor model for adult second language performance. The Monitor, I52-I6I.

Kurt, M. (2015). Which methodology works better? English language teachers' awareness of the innovative language learning methodologies. Education, I35(3), 309-322.

Lasagabaster, D. (20I4). Motivation and foreign language learning from theory to practice. John Benjamins.

Leberman, S. \& McDonald, L. (2006). The transfer of learning participants' perspectives of adult education and training. Aldershot, England: Gower.

Lee, J \& VanPatten, B. (2003). Making communicative language teaching happen (2nd ed.). Columbus, он: McGraw-Hill Education.

Lenneberg, E. H. (I967). The biological foundations of language: A summary. Hospital Practice, 2, 59-67. 
LoMonico, M. (20I4). Teaching English in the world. English Journal, 95(I), II6-II9.

Lorenzo, F., Trujillo, F. \& Vez, J. M. (20II). Educación bilingüe. Integración de contenidos y segundas lenguas. Madrid: Síntesis.

Lou, H. (20I7). Language learning motivation as ideological becoming. System, 65, 69-77.

Meisel, J. (20II). First and second language acquisition: Parallels and differences. Cambridge: Cambridge University Press.

Méndez García, M. (2010). International and intercultural issues in English teaching textbooks: The case of Spain. Intercultural Education, I6(I), 57-68.

Mercer, S. (20II). Towards an Understanding of Language Learner Self-Concept. Springer.

Merriam, S., \& Bierema, L. (20I4). Adult learning: Linking theory and practice. John Wiley \& Sons. Jossey Bass.

Oxford, R. L. (2003). Language learning styles and strategies: An overview. Gala. Learning, I-25.

Park \& Reuter-Lorenz (2009). The adaptive brain: aging and neurocognitive scaffolding. Annual Review of Psychology, 60, 173-96

Piccardo, E. (2010). From Communicative to Action-oriented: New Perspectives for a New Millennium. Contact Tesl Ontario, 36(2), 20-35.

Ramos, S., Fernandez, Y., Anton, E., Casaponsa, A. \& Duabeitia, J. A. (2017). Does learning a language in the elderly enhance switching ability? Journal of Neurolinguistics, 43, 39-48.

Reuter-Lorenz \& Cappell (2008). Neurocognitive aging and the compensation hypothesis. Current directions in psychological science, I7(3), I77-I82

Schmidt-Hertha, B., Krašovec, S. J., Formosa, M. (Eds.). (2014). Learning across generations in Europe: Contemporary issues in older adult education. Rotterdam, Netherlands: Sense Publishers.

Schouten, A. (2009). The Critical Period Hypothesis: Support, challenge, and reconceptualization. Working Papers in TESOL \& Applied Linguistics, 9(I), I-I6.

Scott, E., Zhang, Q. G., Wang, R., Vadlamudi, R. \& Brann, D. (2012). Estrogen neuroprotection and the critical period hypothesis. Frontiers in Neuroendocrinology, 33(I), 85-I04.

Singleton, D. (2005). Age and second language acquisition. Annual Review of Applied Linguistics, 21, 77-89 
Stake, R. E. (2006). Qualitative case studies. In Handbook of Qualitative Research (pp. 443-466). Jossey Bass.

Vanhove, J. (2013). The Critical Period Hypothesis in Second Language Acquisition: A Statistical Critique and a Reanalysis. Plos one, 8(7).

Trofimovich, P. (2OII). Applying priming methods to L2 learning, teaching and

160 research insights from psycholinguistics. Amsterdam: John Benjamins Pub.

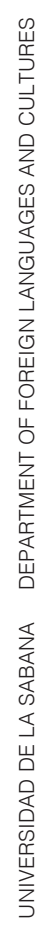

